\title{
Elementary Teachers' Job Satisfiers and Dissatisfier: What Good Professional Development Can Do (SciencePG - Elementary Teacher Job Satisfiers and Dissatisfiers: What Good Professional Development Can Do)
}

\author{
Jennifer Queyrel-Bryan ${ }^{1}$, Kenneth Michael Coll ${ }^{1,}$, , Roger Stewart ${ }^{2,}$, , Stephanie Renee Sawyer ${ }^{1}$ \\ ${ }^{1}$ Counseling and Educational Psychology, University of Nevada, Reno, USA \\ ${ }^{2}$ Literacy, Language, and Culture, Boise State University, Boise, USA
}

Email address:

queyrelb@nevada.unr.edu (J. Queyrel-Bryan),kcoll@unr.edu (K. M. Coll), rstewar@boisestate.edu (R. Stewart),

stephaniesawyer@nevada.unr.edu (S. R. Sawyer)

${ }^{*}$ Corresponding author

\section{To cite this article:}

Jennifer Queyrel-Bryan, Kenneth Michael Coll, Roger Stewart, Stephanie Renee Sawyer. Elementary Teachers' Job Satisfiers and Dissatisfier: What Good Professional Development Can Do (SciencePG- Elementary Teacher Job Satisfiers and Dissatisfiers: What Good Professional Development Can Do). Education Journal. Vol. 8, No. 2, 2019, pp. 63-74. doi: 10.11648/j.edu.20190802.14

Received: February 5, 2019; Accepted: April 17, 2019; Published: May 23, 2019

\begin{abstract}
This study evaluated specific aspects of elementary school teachers' job satisfaction in a large urban public school district. Teachers from ten out of sixty-four elementary schools within a school district in a U.S. western state were surveyed. The elementary schools surveyed included low, medium, and high social economic status schools. This study evaluated (1) the current level of job satisfaction of elementary school teachers and (2) important professional practices that influence teacher job satisfaction. Intrinsic job satisfaction was higher than extrinsic job satisfaction, with overall job satisfaction indicating elementary school teachers were slightly more satisfied than not satisfied. Elementary school teachers were very satisfied with their co-workers, nature of work, and supervision and not satisfied with pay and operating conditions.
\end{abstract}

Keywords: Elementary Education, Job Satisfaction, Professional Practice

\section{Introduction}

Teachers are a valuable human resource in every society [10] yet high attrition rates and retention issues plague the profession. The field of education is facing challenges like never before with high-stakes testing, reduced funding, and additional regulations $[40,48,50]$. Thus, administrators and educators alike are concerned about the increased external demands placed on them with little support; moreover, politicians and the media often incriminate teachers for shortcomings of education $[11,40,50]$. These current conditions have contributed to alarming numbers of teachers leaving the profession of education [16, 29]. However, concurrently, there are also teachers so committed to education that they have stayed in teaching despite the obstacles and difficulties $[15,31,33]$. Thus, it is increasingly important to future retention efforts to understand why some teachers are satisfied with their choice of teaching as a profession while others are not.

Job satisfaction is particularly important within the elementary school level as it provides children with their initial educational experience during their formative years $[9$, 27, 43]. Strong elementary teacher relationships from effective teachers establish life-long positive learning traits [7]. These factors make it imperative to identify the factors among elementary teachers that relate to their job satisfaction.

To this end, this study explored the relationships between professional characteristics and practices and teacher job satisfaction. 296 elementary school teachers were surveyed using the Job Satisfaction Survey (JSS) and a professional characteristics and practices questionnaire.

\subsection{Importance of Job Satisfaction}

Keeping teachers satisfied with their job increases retention $[4,11,4]$. Like other occupations, decreased job satisfaction in 
education has been strongly linked to attrition [1, 3, 35]. Teacher attrition has been shown to directly affect the academic achievement of students, typically because the new replacement teachers often initially lack continuity, knowledge, and experience [6, 18, 20, 26]. However, educators, school administrators, parents, and policy makers need to better understand the factors impacting job satisfaction of teachers in order to effectively address and reduce teacher attrition while also enhancing teacher performance. If not, there will continue to be "serious financial, structural and educational consequences for America's educational system p.27" [24].

It is also particularly important to better understand the factors that contribute to job satisfaction because job satisfaction interfaces with the operation and success of organizations [4, 10, 23]. Effective teachers are considered the key to student learning, so it behooves policymakers, school administration, and society to understand what enhances job satisfaction for teachers which will enhance teacher performance [10]. Researchers such as Darling-Hammond [15], Ingersoll [22, 23], Ingersoll and Smith [25], and Dupriez, Delvaux, and Lothaire [16] have shown that if the key elements are identified that are essential to the job satisfaction of teachers, professionals stand to gain a great deal in strengthening the profession.

\subsection{Purpose of the Study}

The purpose of this quantitative descriptive study was to examine specific elements of job satisfaction of elementary school teachers in a large public urban school district located in a U.S. western state. The school district where the study took take place serves approximately 63,000 students K-12 in roughly 100 schools. There are 64 elementary schools in the district employing approximately 1,300 elementary school teachers. The surveys were administered to ten of the elementary schools composed of low, medium and high (or affluent) social economic status.

\subsection{Primary Research Questions}

(1) What is the current level of job satisfaction of elementary school teachers?

(2) What important professional practices influence teacher job satisfaction?

\section{Method}

\subsection{Participants}

Of the 63,000 students the district serves, approximately 33,200 are at the elementary level [46]. All teachers participating in the study taught at schools located within an urban setting and classified as traditional elementary schools, serving kindergarten through sixth grade students (one school was K-5th). The annual per pupil expenditure in the district is around $\$ 8,400[19,46]$. Because of their non-traditional structure and size, charter schools were excluded from the study. Principals of the schools with teachers participating in the survey had served a minimum of one year at the school site. The school district was composed of a wide socio-economic range; thus, to provide a balanced cross-section of the district's urban elementary schools, teachers from ten facilities with diverse economic backgrounds were invited to participate in the study (see Table 1 for the socio-economic details). Teachers were not asked to identify grade level for which they taught to insure anonymity.

Table 1. Distribution of Participants by Socio-Economic Status of Each School.

\begin{tabular}{llll}
\hline School's Economic Status & School & Participants & Percentage \\
\hline Low & 1 & 32 & $11 \%$ \\
& 2 & 30 & $10 \%$ \\
& 3 & 28 & $9 \%$ \\
Total Low & & 90 & $30 \%$ \\
Median & 4 & 46 & $16 \%$ \\
& 5 & 19 & $3 \%$ \\
Total Median & 6 & 28 & $9 \%$ \\
Affluent & & 93 & $7 \%$ \\
& 7 & 22 & $7 \%$ \\
& 8 & 21 & $11 \%$ \\
Total Affluent & 9 & 33 & $9 \%$ \\
\hline
\end{tabular}

\subsection{Instrumentation}

The instruments employed were the Job Satisfaction Survey (JSS) [44] and a researcher developed demographic and professional practice questionnaire. The Job Satisfaction Survey was utilized in this study because it was specifically written for the human services sector (including schools). Teachers are considered a facet of the human services sector because their profession is based on high interaction with people. The JSS is a 36-question assessment presented in a six-point Likert scale format. "JSS was predicated on the theoretical position that job satisfaction represents an affective or attitudinal reaction to a job, p.694" [44]. Thereby, the JSS was particularly designed to measure attitudinal facets, both individually and in combination [45].

The survey divides the data into nine subscales that include pay, promotion, supervision, fringe benefits, operating conditions, contingent rewards, co-workers, nature of work, 
and communication. The nine subscales pose four questions per subscale intermixing question categories throughout the 36-question survey. Consequently, scores for each of the nine subscales are provided along with an overall satisfaction score. Each of the 36 questions is scored from 1 to 6 on the following scale: disagree very much, disagree moderately, disagree slightly, agree slightly, agree moderately, and agree very much. Therefore, the total score can range between 36 and 216 points.

The JSS "was developed, normed, and validated on human service personnel making it of specific applicability to human services, p.708" [44]. Employing a sample size of 2,870, Spector (1985) found the Job Satisfaction Survey's overall internal consistency to be.91. Subscale reliabilities had coefficient alphas of. 60 or greater with only three of the nine subscales scoring below a coefficient of.73. Research has shown the Job Satisfaction Survey to have acceptable levels of reliability $[44,34]$. While reliability seeks to show consistency in scores, validity seeks to provide evidence that an instrument is measuring what it is designed to measure [15]. Like reliability, a validity coefficient of.70 and higher is an acceptable rate of validity [30]. The JSS has validity coefficients ranging from.61 for coworkers to.80 for supervision [44].

Survey respondents also completed a demographics and professional practices questionnaire the results from which provided a representation of the participating teachers' professional characteristics. The questionnaire was composed of age, ethnicity, marital status, highest level of educational attainment, teacher licensure level, salary, number of schools taught at, years of teaching experience, belief in meaningfulness of professional development, classroom autonomy, belief in the ability to improve the achievement of students, and mentor teacher experience. The demographics did not ask a gender question because there were so few male participants that anonymity of responses might be compromised.

\subsection{Research Design}

The professional characteristic variables were the independent variables and the two dependent variables were derived from the JSS by aggregating subscales from the instrument. One dependent variable consisted of the intrinsic satisfiers contingent rewards, co-workers, nature of work, and communication. The other dependent variable consisted of the extrinsic dissatisfiers of pay, promotion, supervision, fringe benefits, and operating conditions. In order to analyze whether the independent variables of the professional characteristics data had significant relationships to the two aggregated dependent variables of the Job Satisfaction Survey, a multiple analysis of variance (MANOVA) was employed. A MANOVA was selected because the differences in means between multiple groups were analyzed with two dependent variables.

\subsection{Data Collection}

Permission from the University's Institutional Review Board (IRB) was obtained to administer the Job Satisfaction Survey along with the professional characteristics questionnaire. Upon IRB approval permission to conduct the survey was also obtained from the Office of Accountability and Performance at the school district. The authors invited ten elementary schools within the school district to participate based upon a balanced representation of schools from three socioeconomic status (SES) sectors based upon the number of FRPL (free and reduced price lunch): (a) low social-economic - FRPL greater than $80 \%$, (b) median economic, FRPL between 40 and $60 \%$, and (c) affluent status - FRPL equal to or less than $15 \%$.

An introductory e-mail was sent to the principals of ten identified elementary schools spanning the SES categories to explain the purpose and significance of the study, seek their permission to access their schools, and invite their teachers to voluntarily participate in the study. It was suggested to the principals that the surveys would optimally be administered just prior to commencing a staff meeting or professional development workshop. Follow-up contact was made to principals who did not reply within seven business days.

Following successful contact with the ten school principals who provided permission to access their schools, an e-mail was sent to the principals to establish a date and time for the survey to be administered. In order to administer the surveys and accommodate principals' calendars, one assistant (or survey proctor) was trained to assist the lead author and serve as an additional survey proctor in case of a scheduling conflict or illness on the part of the researcher. The survey proctor was not a teacher or supervisor within the district where the survey was administered. One week prior to each school's survey date, an introductory e-mail was sent to every teacher on staff informing them that they would be asked to take a survey in the upcoming week, where and how the survey would be administered, and the purpose of the survey. They were informed at this time that completing the survey was voluntary.

\section{Results}

A total of 296 (286 were usable) elementary teachers participated in the survey from the group of ten schools resulting in a response rate $60 \%$. The respondents' personal and professional characteristics are summarized in Table 2 (below).

Table 2. Personal Characteristics.

\begin{tabular}{lll}
\hline Personal Characteristics $(\mathbf{N}=\mathbf{2 9 6})$ & & \\
\hline Personal Demographic Characteristic & Percent & \\
\hline Age Group & & \\
$1.21-30$ years & $20.6 \%$ & 61 \\
$2.31-40$ years & $26.7 \%$ & 79 \\
$3.41-50$ years & $30.7 \%$ & 91 \\
\hline
\end{tabular}




\begin{tabular}{|c|c|c|}
\hline \multicolumn{3}{|l|}{ Personal Characteristics $(\mathrm{N}=296)$} \\
\hline Personal Demographic Characteristic & Percent & $(\mathbf{N})$ \\
\hline 4. $51+$ years & $22.0 \%$ & 65 \\
\hline \multicolumn{3}{|l|}{ Ethnicity } \\
\hline 1. White & $89.8 \%$ & 265 \\
\hline 2. Non-White & $10.2 \%$ & 30 \\
\hline \multicolumn{3}{|l|}{ Marital Status } \\
\hline 1. Married & $64.4 \%$ & 188 \\
\hline 2. Not Married & $35.6 \%$ & 104 \\
\hline \multicolumn{3}{|l|}{ Salary } \\
\hline 1. $\$ 35,000-\$ 42,999$ & $29.4 \%$ & 85 \\
\hline 2. $\$ 43,000-\$ 49,999$ & $26.0 \%$ & 75 \\
\hline 3. $\$ 50,000-\$ 58,999$ & $24.2 \%$ & 70 \\
\hline 4. $\$ 59,000+$ & $20.4 \%$ & 59 \\
\hline \multicolumn{3}{|l|}{ Educational Attainment } \\
\hline 1. Bachelor's Degree & $15.2 \%$ & 45 \\
\hline 2. Bachelor's + Graduate Credit & $26.7 \%$ & 79 \\
\hline 3. Graduate Degree & $58.1 \%$ & 172 \\
\hline \multicolumn{3}{|l|}{ Teaching Credential/License } \\
\hline 1. Only Elementary & $74.8 \%$ & 220 \\
\hline 2. Only Secondary & $0.7 \%$ & 2 \\
\hline 3. Both Elementary \& Secondary & $24.5 \%$ & 72 \\
\hline \multicolumn{3}{|l|}{ Number of Schools Taught } \\
\hline 1. 1 School & $21.3 \%$ & 63 \\
\hline 2. 2 -3 Schools & $49.0 \%$ & 145 \\
\hline 3. $4-5$ Schools & $19.9 \%$ & 59 \\
\hline 4. 6 or more schools & $9.8 \%$ & 29 \\
\hline \multicolumn{3}{|l|}{ Teaching Experience } \\
\hline 1-6 Years & $33.21 \%$ & 97 \\
\hline 7-15 Years & $33.54 \%$ & 98 \\
\hline 16-41 Years & $33.21 \%$ & 97 \\
\hline \multicolumn{3}{|l|}{ Meaningfulness of PD } \\
\hline 1. Not at All & $12.5 \%$ & 37 \\
\hline 2. Sometimes & $67.2 \%$ & 199 \\
\hline 3. Most of the Time & $20.3 \%$ & 60 \\
\hline \multicolumn{3}{|l|}{ Have Classroom Autonomy } \\
\hline 1. Yes & $41.2 \%$ & 122 \\
\hline 2. No & $12.5 \%$ & 37 \\
\hline 3. Some of the Time & $46.3 \%$ & 137 \\
\hline \multicolumn{3}{|c|}{ Belief in Ability to Improve the Achievement of Students } \\
\hline 1. Few to Some & $7.8 \%$ & 23 \\
\hline 2. Most & $61.8 \%$ & 183 \\
\hline 3. All & $30.4 \%$ & 90 \\
\hline \multicolumn{3}{|l|}{ Had Access to a Mentor Teacher } \\
\hline 1. Yes & $42.9 \%$ & 127 \\
\hline 2. No & $57.1 \%$ & 169 \\
\hline
\end{tabular}

When the demographic and professional practices questionnaire results were aggregated the means provided the following portrait of an average respondent as seen in Table 3 (below).

Table 3. Portrait of Average Respondent.

\begin{tabular}{l} 
Portrait of Average Respondent \\
Average Responses \\
Demographic Info \\
41-50 Years of Age \\
White \\
Married \\
Salary \\
Annual Salary Range of $\$ 35,000-\$ 42,999$ \\
Licensing and Education \\
Holds an Elementary Only Teaching License \\
Holds a Graduate Degree \\
Teaching Experiences \\
Taught at 2-3 Schools \\
Has 12.5 Years of Teaching Experience \\
\hline
\end{tabular}




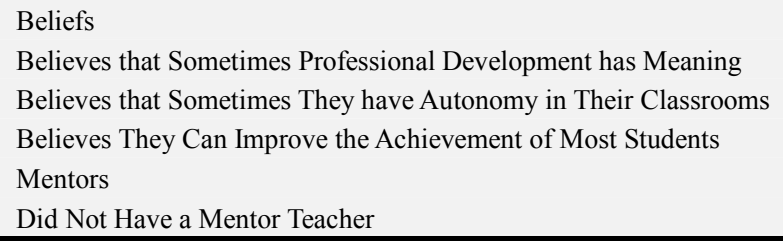

\subsection{Research Question One: What Is the Current Level of Job Satisfaction of Elementary School Teachers}

Generally, teachers were moderately satisfied with their co-workers, nature of work, and supervision. See Figure 1 for the means of the subscales of the JSS. They were dissatisfied with their pay and operating conditions. Overall participants were slightly more satisfied than dissatisfied, and they were more satisfied with their intrinsic job satisfaction factors than their extrinsic job satisfaction factors. However, as a group, the lowest socioeconomic group was most satisfied overall, followed by the median socioeconomic category. The affluent category reported the lowest in overall satisfaction.

The overall results of the Job Satisfaction Survey indicated that intrinsic job satisfaction (Mean=4.36) scored higher than extrinsic job satisfaction (Mean=3.28) with an overall job satisfaction mean score of 3.76 , indicating teachers were slightly more satisfied than not satisfied. The scores from the individual job satisfaction subscales indicated that teachers were very satisfied with their co-workers, nature of work, and supervision with means of 5.00, 5.02, and 5.39 respectively. Pay and operating conditions had the lowest means at 2.38 and 2.39 respectively.

The means of the nine sub-scales, the intrinsic factors, the extrinsic factors, and the overall Job Satisfaction scores are indicated in Figure 1 (below). Scores are based on a score of 1 to 6 where 1 is low satisfaction and 6 is high satisfaction.

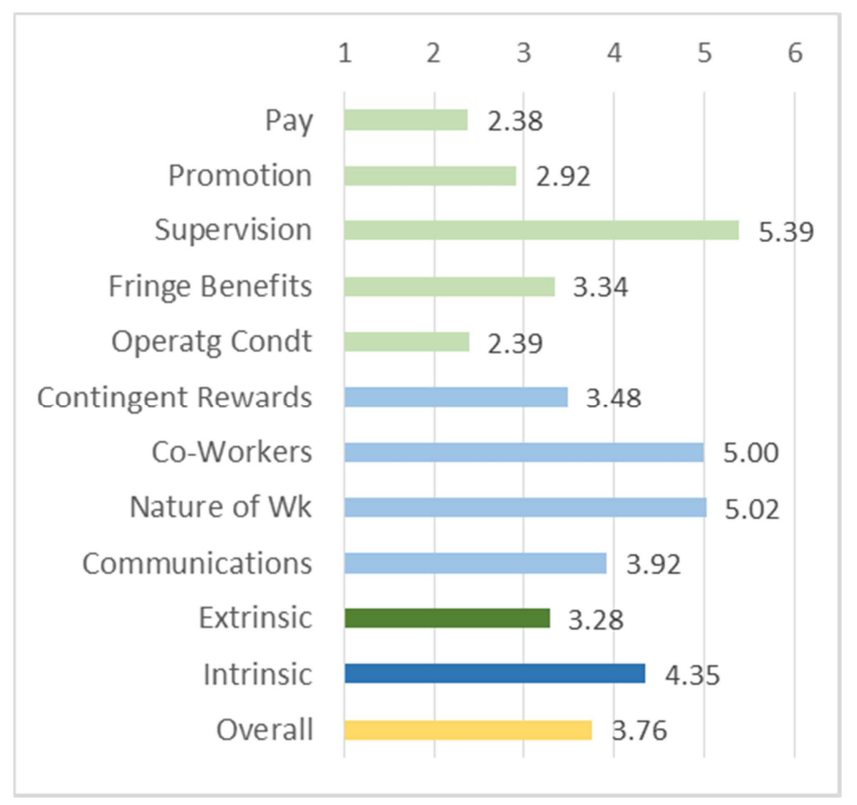

Figure 1. Means of Job Satisfaction Survey Results.

Significant results indicate that the characteristics of the most satisfied teachers were indicated in Table 4 (below).

Table 4. Characteristics of the Most Satisfied Teachers.

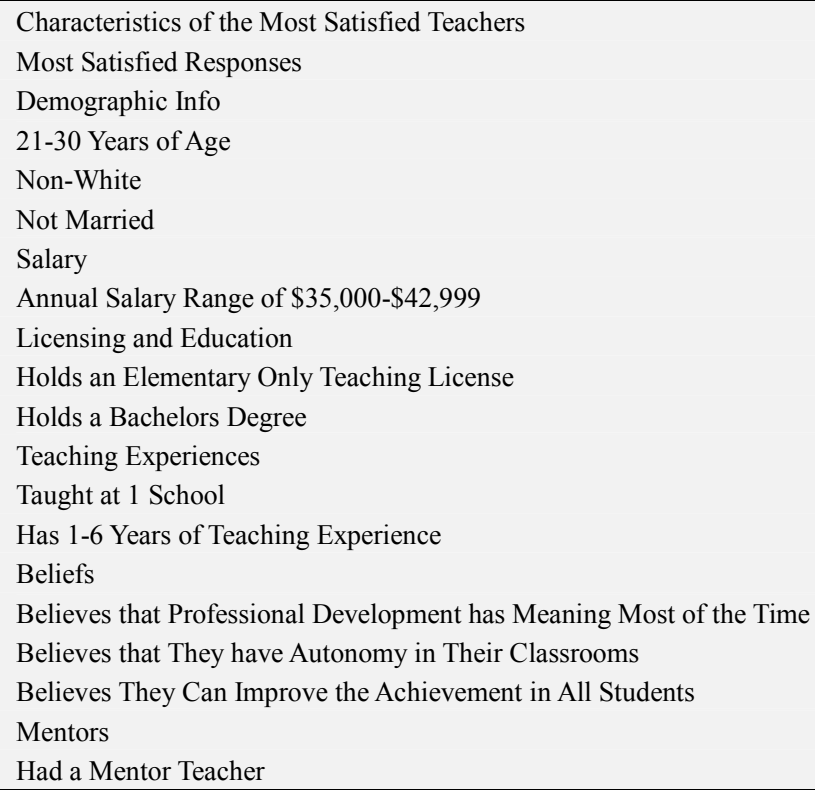

Significant results indicate that those teachers with the least job satisfaction exhibited in the characteristics seen in Table 5 
(below).

Table 5. Characteristics of Least Satisfied Teachers.

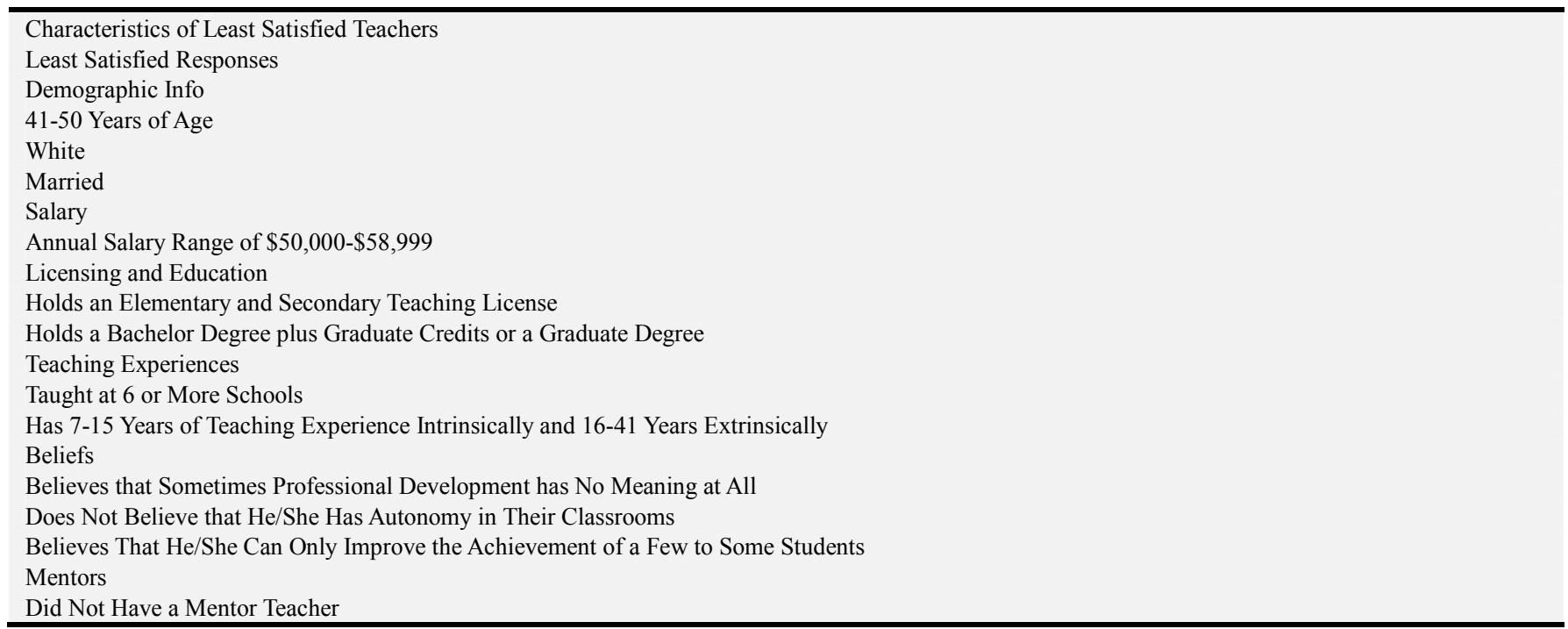

\subsection{Research Question Two: Which Professional Practices Influence Elementary Teacher Job Satisfaction}

The MANOVA results indicated that statistically significant differences did exist among the extrinsic job satisfaction dependent variables and the independent variables of age and the number of schools in which a teacher has taught.

MANOVA results also indicated significant differences existed among the intrinsic and extrinsic dependent variables of job satisfaction and the independent variables of salary, total years of teaching experience, one's belief in professional development, having classroom autonomy, and one's belief in the ability to improve student achievement. No significant differences were found within ethnicity, marital status, level of education, level of teacher licensing, or mentor experience groups.

Specific statistical findings for each of the professional practices questions (with $\mathrm{p}<.05$ bolded) are found in Table 6 (below).

Table 6. Group Differences Post Hoc Tests.

\begin{tabular}{lll}
\hline Group Differences Post Hoc Tests & & Significance \\
\hline Personal Demographic Characteristic & & Salue \\
\hline Age \& Extrinsic Job Satisfaction & Not Significant & $\mathrm{P}=.012$ \\
Difference between Age Group 1 \& Group 3 & Not Significant & $\mathrm{P}=.069$ \\
Difference between Age Group 1 \& Group 2 & Not Significant & $\mathrm{P}=.116$ \\
Difference between Age Group 1 \& Group 4 & Not Significant & $\mathrm{P}=.938$ \\
Difference between Age Group 2 \& Group 3 & Not Significant & $\mathrm{P}=.999$ \\
Difference between Age Group 2 \& Group 4 & & $\mathrm{P}=.907$ \\
Difference between Age Group 3 \& Group 4 & Significant & $\mathrm{P}=.044$ \\
Number of Schools Taught in \& Extrinsic Job Satisfaction & Not Significant & $\mathrm{P}=.139$ \\
Difference between Schools Group 1 \& Group 4 & Not Significant & $\mathrm{P}=.077$ \\
Difference between Schools Group 1 \& Group 2 & Not Significant & $\mathrm{P}=.887$ \\
Difference between Schools Group 1 \& Group 3 & Not Significant & $\mathrm{P}=.562$ \\
Difference between Schools Group 2 \& Group 3 & Not Significant & $\mathrm{P}=.907$ \\
Difference between Schools Group 2 \& Group 4 & & $\mathrm{P}=.001$ \\
Difference between Schools Group 3 \& Group 4 & Significant & $\mathrm{P}=.491$ \\
Salary \& Intrinsic Job Satisfaction & Not Significant & $\mathrm{P}=.947$ \\
Difference between Salary Group 1 \& Group 3 & Not Significant & $\mathrm{P}=.093$ \\
Difference between Salary Group 1 \& Group 2 & Not Significant & $\mathrm{P}=.875$ \\
Difference between Salary Group 1 \& Group 4 & Not Significant & $\mathrm{P}=.019$ \\
Difference between Salary Group 2 \& Group 3 & Significant & \\
Difference between Salary Group 2 \& Group 4 & & $\mathrm{P}<.001$ \\
Difference between Salary Group 3 \& Group 4 & Significant & $\mathrm{P}=.337$ \\
Salary \& Extrinsic Job Satisfaction & Not Significant & $\mathrm{P}=.760$ \\
Difference between Salary Group 1 \& Group 3 & Not Significant & $\mathrm{P}=.048$ \\
Difference between Salary Group 1 \& Group 2 & Significant & $\mathrm{P}=.940$ \\
Difference between Salary Group 1 \& Group 4 & Not Significant & \\
Difference between Salary Group 2 \& Group 3 & & \\
Difference between Salary Group 2 \& Group 4 & & \\
\hline
\end{tabular}




\begin{tabular}{|c|c|c|}
\hline \multicolumn{3}{|l|}{ Group Differences Post Hoc Tests } \\
\hline Personal Demographic Characteristic & Significance & P Value \\
\hline Difference between Salary Group 3 \& Group 4 & Significant & $\mathrm{P}=.015$ \\
\hline \multicolumn{3}{|l|}{ Years of Teaching Experience \& Intrinsic Job Satisfaction } \\
\hline Difference between Teaching Group 1 \& Group 2 & Significant & $\mathrm{P}=.006$ \\
\hline Difference between Teaching Group $1 \&$ Group 3 & Significant & $\mathrm{P}=.007$ \\
\hline Difference between Teaching Group $2 \&$ Group 3 & Not Significant & $\mathrm{P}=.998$ \\
\hline \multicolumn{3}{|l|}{ Years of Teaching Experience \& Extrinsic Job Satisfaction } \\
\hline Difference between Teaching Group 1 \& Group 2 & Significant & $\mathrm{P}=.001$ \\
\hline Difference between Teaching Group $1 \&$ Group 3 & Significant & $\mathrm{P}=.001$ \\
\hline Difference between Teaching Group $2 \&$ Group 3 & Not Significant & $\mathrm{P}=.990$ \\
\hline \multicolumn{3}{|c|}{ Meaningfulness of Professional Development \& Intrinsic Job Satisfaction } \\
\hline Difference between Meaningfulness Group 1 \& Group 2 & Significant & $\mathrm{P}<.001$ \\
\hline Difference between Meaningfulness Group $1 \&$ Group 3 & Significant & $\mathrm{P}<.001$ \\
\hline Difference between Meaningfulness Group $2 \&$ Group 3 & Significant & $\mathrm{P}<.001$ \\
\hline \multicolumn{3}{|c|}{ Meaningfulness of Professional Development \& Extrinsic Job Satisfaction } \\
\hline Difference between Meaningfulness Group 1 \& Group 2 & Significant & $\mathrm{P}<.001$ \\
\hline Difference between Meaningfulness Group $1 \&$ Group 3 & Significant & $\mathrm{P}<.001$ \\
\hline Difference between Meaningfulness Group 2 \& Group 3 & Significant & $\mathrm{P}<.001$ \\
\hline \multicolumn{3}{|l|}{ Classroom Autonomy \& Intrinsic Job Satisfaction } \\
\hline Difference between Teaching Group 1 \& Group 2 & Significant & $\mathrm{P}<.001$ \\
\hline Difference between Teaching Group $1 \&$ Group 3 & Significant & $\mathrm{P}=.002$ \\
\hline Difference between Teaching Group $2 \&$ Group 3 & Significant & $\mathrm{P}<.001$ \\
\hline \multicolumn{3}{|l|}{ Classroom Autonomy \& Extrinsic Job Satisfaction } \\
\hline Difference between Teaching Group 1 \& Group 2 & Significant & $\mathrm{P}<.001$ \\
\hline Difference between Teaching Group $1 \&$ Group 3 & Significant & $\mathrm{P}=.002$ \\
\hline Difference between Teaching Group $2 \&$ Group 3 & Significant & $\mathrm{P}<.001$ \\
\hline \multicolumn{3}{|c|}{ Belief in the Ability to Improve the Achievement of Students \& Intrinsic Job Satisfaction } \\
\hline Difference between Teaching Group 1 \& Group 2 & Significant & $\mathrm{P}<.001$ \\
\hline Difference between Teaching Group $1 \&$ Group 3 & Significant & $\mathrm{P}<.001$ \\
\hline Difference between Teaching Group 2 \& Group 3 & Significant & $\mathrm{P}=.011$ \\
\hline \multicolumn{3}{|c|}{ Belief in the Ability to Improve the Achievement of Students \& Extrinsic Job Satisfaction } \\
\hline Difference between Teaching Group 1 \& Group 2 & Significant & $\mathrm{P}<.001$ \\
\hline Difference between Teaching Group $1 \&$ Group 3 & Significant & $\mathrm{P}<.001$ \\
\hline Difference between Teaching Group 2 \& Group 3 & Significant & $\mathrm{P}=.022$ \\
\hline
\end{tabular}

1) Age: The Tukey post hoc test identified that significant differences existed only in the extrinsic subscale. The results indicated that for extrinsic job satisfaction, Age group 1 (21-30 years) had a statistically significant higher mean score than participants from Age group 3 (41-50 years) ( $p=.012)$, but not between Age groups $2(31-40$ years) $(p=.069)$ or $4(51+$ years $)$ $(p=.116)$. There was no statistically significant differences between Age group 2 to $3(p=.938)$ group 2 to $4(p=.999)$, or group 3 to $4(p=.907)$.

2) Number of Schools Taught in: The Tukey post hoc test identified that significant differences existed in only the extrinsic subscale. The results indicated that for extrinsic job satisfaction Number of Schools Taught at group 1 (one school) had a statistically significant higher mean score than participants from Number of Schools Taught at group 4 (six or more schools) $(p=.044)$, but not between Number of Schools Taught at groups 2 (two to three schools) $(p=.139)$ or 3 (four to five schools) $(p=.077)$. There was no statistically significant differences between Number of Schools Taught at group 2 to 3 ( $p=.887$ ) group 2 to 4 ( $p=.562$ ), or group 3 to 4 ( $p$ $=.907$ ).

3) Salary: The Tukey post hoc test identified that significant differences existed in both the intrinsic and extrinsic subscales. Tukey post hoc tests indicated that for intrinsic job satisfaction Salary group $1 \quad(\$ 35,000-\$ 42,999)$ had a statistically significant higher mean score than participants from Salary group $3(\$ 50,000-58,999)(p=.001)$, but not between Salary groups $2(\$ 43,000-\$ 49,999)(p=.491)$ or $4(\$ 59,000+)(p$ $=.947)$. Salary group 2 did not have any statistically different mean scores between $3(p=.093)$ and $4(p=.875)$. Salary group 3 indicated it had a statistically significant lower mean score than participants from Salary group $4(p=.019)$.

Tukey post hoc tests indicated that for extrinsic job satisfaction Salary group 1 had a statistically significant higher mean score than participants from Salary group 3 ( $p$ $<.001)$, but not between Salary groups $2(p=.337)$ or 4 ( $p$ $=.760$ ). Salary group 2 had a statistically significant higher mean score between group $3(p=.048)$, but not $4(p=.940)$. Salary group 3 indicated it had a statistically significant lower mean score than participants from Salary group $4(p=.015)$.

4) Years of Teaching Experience: The Tukey post hoc test identified that significant differences existed in both the intrinsic and extrinsic subscales. Tukey post hoc tests indicated that for intrinsic job satisfaction Total Years of Teaching Experience group 1 (0-6 years) had a statistically significant higher mean score than participants from Total Years of Teaching Experience group 2 (7-15 years) ( $p=.006)$ and group $3(16+)(p=.007)$. There was no significant difference between group 2 to group $3(p=.998)$.

Tukey post hoc tests indicated that for extrinsic job satisfaction Total Years of Teaching Experience group 1 had a statistically significant higher mean score than group $2(p$ $=.001)$ and group $3(p=.001)$. There was no statistically significant difference between group 2 to group $3(p=.990)$. 
5) Meaningfulness of Professional Development: The Tukey post hoc test identified that significant differences existed in both the intrinsic and extrinsic subscales. Tukey post hoc tests indicated that for intrinsic job satisfaction belief in Professional Development group 1 (not at all) had a statistically significant lower mean score than participants from belief in Professional Development group 2 (sometimes) $(p<.001)$ and group 3 (most of the time) $(p<.001)$. Belief in Professional Development group 2 indicated it had a statistically significant lower mean score than participants from Professional Development group $3(\mathrm{p}<.001)$.

Tukey post hoc tests indicated that for extrinsic job satisfaction belief in Professional Development group 1 had a statistically significant lower mean score than participants from belief in Professional Development group $2(p<.001)$ and group $3(p<.001)$. Belief in Professional Development group 2 indicated it had a statistically significant lower mean score than participants from Professional Development group $3(p<.001)$.

6) Classroom Autonomy: The Tukey post hoc test identified that significant differences existed in both the intrinsic and extrinsic subscales. Tukey post hoc tests indicated that for intrinsic job satisfaction Classroom Autonomy group 1 (yes) had a statistically significant higher mean score than participants from Classroom Autonomy group 2 (no) $(p<.001)$ and group 3 (some of the time) $(p=.002)$. Classroom Autonomy group 2 indicated it had a statistically significant lower mean score than participants from Professional Development group $3(p<.001)$.

Tukey post hoc tests indicated that for extrinsic job satisfaction Classroom Autonomy group 1 had a statistically significant higher mean score than participants from Classroom Autonomy group $2(p<.001)$ and group $3(p=.002)$. Classroom Autonomy group 2 indicated it had a statistically significant lower mean score than participants from Professional Development group $3(p<.001)$.

7) Belief in the Ability to Improve the Achievement of Students: The Tukey post hoc test identified that significant differences existed in both the intrinsic and extrinsic subscales. Tukey post hoc tests indicated that for intrinsic job satisfaction belief in the Improvement of Achievement of Students group 1 (few to some) had a statistically significant lower mean score than participants from belief in the Improvement of Achievement of Students group 2 (most) $(p<.001)$ and group 3 (all) $(p<.001)$. Group 2 had a statistically significant lower mean score than group $3(p=.011)$.

Tukey post hoc tests indicated that for extrinsic job satisfaction belief in the improvement of Achievement of Students group 1 had a statistically significant lower mean score than participants from belief in the Improvement of Achievement of Students group $2(p<.001)$ and group $3(p$ $<.001)$. Group 2 had a statistically significant lower mean score than group $3(\mathrm{p}=.022)$.

\section{Discussion}

The overall results indicated that intrinsic job satisfaction was higher than extrinsic job satisfaction, with overall job satisfaction indicating elementary school teachers were slightly more satisfied than not satisfied. Elementary school teachers were very satisfied with their co-workers, nature of work, and supervision and not satisfied with pay and operating conditions.

The results from this study also indicate that 1) age, 2) number of schools a teacher has taught in, 3) salary, 4) total years of teaching experience, 5) professional development, 6) classroom autonomy, and 7) belief in the ability to improve the achievement of students have significant effects on elementary school teacher job satisfaction.

The younger teachers, both in age and teaching experience, are more satisfied than their older and more experienced co-workers. As might be expected, age often factors into one's level of education, experience, and salary, and so these variables are often found in combination. Young educators would have less experience and would likely earn less than those with more years. Those with more years of experience will be older. The term, young educators, however, can be misleading because while 'young' can denote age, it neglects second career teachers who are older in years, but are beginning teachers, young in their career.

The results of this study are misleading if the message is to only hire new, young teachers. Such advice would be neglecting some key points. First, young teachers will get older. Second, a large number of new teachers leave the field of education in the first five years; some studies note as high as $50 \%$ [24]. It is also important to indicate that while experienced teachers are more dissatisfied than the beginning teachers, it is the experienced teachers who bring continuity, knowledge, experience, mentoring, and understanding to the classroom and these teachers become even more valuable to the academic success of students $[6,18,20,24,26]$. Bandura [5] pointed out that one's self-efficacy can be highly motivational in the beginning of a new task, a major factor in a young teacher's first years because it is not just about one's proven ability. Tschannen-Moran and Woolfolk-Hoy [47] found that educational resources and interpersonal support from administrators, fellow teachers, and the community also played a prominent role in supporting novice teachers. They found this kind of support can maintain and reinforce the self-efficacy of new teachers, which in turn benefits job satisfaction [47]. Conversely, when a new teacher encounters more challenges than expected, the reality of the difficulty can impact his/her self-efficacy with self-doubt [49]. Depending on the individual and the impact of the situation it will either further deteriorate one's efficacy or motivate the teacher to seek solutions to the problem thus enhancing efficacy (intrinsic factor) [51].

The number of schools a teacher has taught in corresponds with the teacher's level of job satisfaction. The more schools a teacher had been at, the lower their satisfaction. The teachers at their first school were the highest satisfied, again pointing to the younger teachers. Those with experience at six or more schools were the least satisfied and likely have a low sense of efficacy (intrinsic factor) [39]. 
When someone is underpaid in a job, over time, it often brings dissatisfaction. Most everyone would agree that teachers are underpaid and this presumably results in dissatisfaction over time, but being dissatisfied is not a single result. Currall, Towler, Judge, \& Kohn [14] found in a study of over six thousand teachers that teacher satisfaction with pay was directly attributed to the academic performance of their students. Thus, dissatisfaction can trigger other employee performance outcomes such as lower academic achievement.

There were three professional practices that had a significant effect on elementary teacher job satisfaction. These professional practices were professional development opportunities, classroom autonomy, and belief in ability to improve the achievement of students. Of note is that while mentoring may be beneficial to elementary teachers, and while approximately half of the teachers in this study had received some form of mentoring, it did not result in a significant difference in job satisfaction in this study.

Professional development provides opportunities for professional and personal growth. Even when it is a "vicarious experience" it provides teachers with skill building opportunities that in turn bolster efficacy (intrinsic factor) [47] The impact or level of learning the opportunity provides is weighted against how much the teacher identifies with the value added to their teaching [47]. Professional development can occur in many forms, from large audience presentation, to small group conferencing, to individualized instruction. Its options are almost endless.

Classroom autonomy also had a significant influence on elementary teacher job satisfaction. Ingersoll, Merrill, and Stuckey [24] found when teachers feel they have decision-making discretion over what their students need and have a voice over what is best for their facility and faculty they are more satisfied. The ability to communicate and relate well with co-workers, organize and manage job demands, exhibit leadership qualities, and ability to manage job stress all stem from strong self-efficacy traits and support autonomy [21]. The more autonomy teachers have in their professional decisions at school, the greater their self-efficacy (intrinsic factor) [47] and the greater their satisfaction. Learning to provide and participate in autonomous environments is a growth opportunity for principals as well as teachers, but it is one that aids satisfaction.

Finally, job satisfaction is greater with those teachers who believe they can improve the academic achievement of their students. Teachers who have positive self-efficacy foster motivation and self-efficacy (intrinsic factor) in their students [42] and students who have good self-efficacy tend to be more successful, in turn motivating their teachers and feeding their self-efficacy; it is a reciprocal effect [39]. Educators with commitment to student achievement are typically more dedicated and exhibit higher job satisfaction $[5,8]$.

\subsection{Implications for Practice}

\subsubsection{Professional Development}

The independent variable of professional development has strong implications for practice and influences several aspects of education; from administration, to teachers, to students. Professional development is wide-ranging, always dynamic, and can embrace nearly every aspect of job satisfaction. Its importance to job satisfaction cannot be underscored enough, as it drives so many elements. The majority of teachers in this study often found professional development meaningful; only $12.5 \%$ reported they did not believe it was meaningful. Professional development can address a myriad of growth factors for teachers from enhancing methodology, to autonomy, to improving student achievement. Karabiyik and Korumaz's [27] research noted that teachers not only approve of 'good' professional development, they documented it raised job satisfaction. District resources for professional development opportunities can positively benefit a majority of educators versus some programs that only interface with a small selection of teachers, like mentoring.

And professional development opportunities can be found in a variety of formats; from single presenter with a large audience, to collaborating teachers at a single school site. Professional development is not just hiring an outside consultant or speaker, schools in themselves, have proficient, experienced, professional educators who are enthusiastic and honored to share their knowledge. In fact, "teacher-led development also increases ownership and engagement among teachers of all levels" [2]. In house or in district professional development opportunities are not only readily accessible and highly valuable tools they are also cost conscious.

\subsubsection{Autonomy}

Autonomy was also shown to significantly improve job satisfaction. The professional practice of autonomy has been shown in other studies to be motivational and valued by teachers [37]. Perie \& Baker [36] found autonomy to be essential to a favorable work environment that resulted in higher job satisfaction; by contrast, when teachers perceive it is not present they were dissatisfied. This result was evidenced in this study. Further, the definition of autonomy may also change as the teacher gains experience. What a first or second year teacher deems autonomous may vary greatly from what a 12 th or 13 th year teach deems autonomous. It is therefore also important to consider how autonomy changes over time for people. Getting school principals and school district administrators to recognize teachers as the educational leaders of their students and classrooms and co-leaders of school-wide procedures, will lead to higher job satisfaction [36].

\subsubsection{Improving Academic Achievement}

Teachers who believe they can improve the academic achievement of students were shown to be more satisfied and this belief influences positive student achievement. Mojavezia and Tamiz [32] found in their study that student achievement was directly related to teachers' self-efficacy because teachers with high efficacy want to teach and want their students to learn. These teachers employ innovative teaching methods, which encourage student participation [32]. Students who are engaged are less likely to be off-task and disruptive, and engaged students are learning. Higher job satisfaction through 
believing in the ability to improve student achievement can actually reduce the achievement gap of students [37]. Investing in teacher preparation and professional development are direct routes by which to improve teacher efficacy and student achievement [37]. Another route to explore are alternative pay options, wherein teachers may receive a stipend for their leadership roles within a school and their contributions to school wide achievement. This also strengthens autonomy.

\subsection{Limitations and Recommendations for Further Research}

Future research should seek to gain a better understanding of which independent variables working in combination impact job satisfaction would provide greater depth to job satisfaction factors. It would also be helpful to examine methods to engage teachers who do not find professional development meaningful. Researchers should include the examination of school climate as part of the professional practices that contribute to teacher job satisfaction $[28,47]$.

It would be useful to be able to identify the cause from the effect for the dissatisfaction of teachers who have taught at over six schools: a) are these teachers dissatisfied because they have moved from school to school, or b) are these teachers moving from school to school because they dissatisfied, or c) are these teachers choosing to change schools or has administration moved them?

While self-efficacy has been studied at lengths in the 1980's and 1990's recent research has waned; continued research in the subject matter and its interaction with job satisfaction would be beneficial. Expansion of the study of job satisfaction of other school professionals (counselors, school psychologists, school nurses, etc.) may also be valuable in building a more complete representation of job satisfaction within the field of education.

Although the data gathered in this study is not meant to be generalizable per se, certain aspects or conditions could be of use to other western school districts with analogous demographic compositions under some circumstances. There are twenty-eight school districts located in the western United States that share similar demographics to the district under study $[19,17,38]$. The six western states of comparison are Arizona, California, Colorado, Nevada, Texas, and Utah.

\section{Conclusion}

In this study, statistical significance was found among age, the number of schools a teacher had taught at, salary, total years of teaching experience, meaningfulness of professional development, the feelings of autonomy, and the belief in the ability to improve the academic achievement of students. This study's results imply that job satisfaction can be improved through the professional practices of professional development, promoting autonomy, and enriching teachers' beliefs in their ability to improve student achievement. Mentoring was not shown to significantly effect job satisfaction.

Job satisfaction is key to retaining teachers and curbing attrition as the professional research clearly indicates. In turn, it can support school districts on several fronts, from reducing employee costs to improving student achievement. Each district is different and each must consider the varying needs of their community's teachers. This can only be accomplished by continuously monitoring the pulse of one's school community along with understanding the changing needs of education and society. Teacher job satisfaction will never be a static topic.

\section{References}

[1] Anhorn, R. (2008). The profession that eats its young. The Delta Kappa Gamma Bulletin Spring 2008, 15-26.

[2] Arnett, A. (2017, May 4). To develop teachers, look to other teachers. Education Drive. Retrieved from http://www.educationdive.com/news/to-develop-teachers-look -to-other- teachers/441953/.

[3] Arnett, S. E. \& Polkinghorne, F. W. (2010). Job dissatisfaction: a factor in maintaining a highly- qualified family and consumers' sciences teacher workforce. Online Journal of Workforce Education and Development IV (4).

[4] Aydogdu, S. \& Asikgil, B. (2011). An empirical study of the relationship among job satisfaction, Organizational commitment and turnover intention. International Review of Management and Marketing, 1 (3), 43-53.

[5] Bandura, A. (1997). Self-efficacy: The exercise of control. New York, NY: W. H. Freeman \& Co.

[6] Billingsley, B. S. (2004). Special education teacher retention and attrition: A critical analysis of the research literature. Journal of Special Education, 38 (1), 39-56. doi: $10.1177 / 00224669040380010401$

[7] Birch, S. H., \& Ladd, G. W. (1996). Interpersonal relationships in the school environment and children's early school adjustment: The role of teachers and peers. In J. Juvonen \& K. R. Wentzel (Eds.), Social motivation: Understanding children's school adjustment (pp. 199- 225). New York: Cambridge University Press.

[8] Caprara, G. V., Barbaranelli, C., Borgogni, L., Petitta, L., \& Rubinacci, A. (2003). Teachers', school staff's and parents' efficacy beliefs as determinants of attitude toward school. European Journal of Psychology of Education, 18 (1), 15-31. Retrieved http://www.jstor.org.unr.idm.oclc.org/stable/23420375

[9] Caprara, G. V., Barbaranelli, C., Steca, P., \& Malone, P. S. (2006). Teachers' self-efficacy beliefs as determinants of job satisfaction and students' academic achievement: A study at the school level. Journal of School Psychology 44 (6), 473-490. Retrieved from http://ac.elscdn.com.unr.idm.oclc.org/S0022440506000847/1-s2.0-S0022 440506000847main.pdf?_tid=063145a8-0f25-11e6-8f7800000aab0f02\&acdnat $=1462056417$ b8cb31537454d97b1801 aae2742528bd.

[10] Chamundeswari, S. (2013). Job satisfaction and performance of school teachers. International Journal of Academic Research in Business and Social Sciences, 3 (5) 420-428. Retrieved from http://www.hrmars.com/admin/pics/1859.pdf. 
[11] Cockburn, A. D. \& Haydn, T. (2004). Recruiting and retaining teachers: Understanding why teachers teach. New York, NY: Routledge Falmer.

[12] Comber, B. \& Nixon H. (2009). Teachers' work and pedagogy in an era of accountability. Discourse: Studies in the Cultural Politics of Education, 30 (3), 333-345. Retrieved from http://web.a.ebscohost.com.unr.idm.oclc.org/ehost/pdfviewer/ pdfviewer?vid $=2 \&$ sid $=$ bf 26

37f8-79fc-496d-998b-edb4fa7eeb70\%40sessionmgr4003\&hid $=4112$.

[13] Creswell, J. W. (2015). Educational research: Planning conducting, and evaluating quantitative and qualitative research (5th ed.). [Kindle edition] Pearson Education, Inc.

[14] Currall, S. C., Towler, A. J., Judge, T. A. and Kohn, N, L. (2005). Pay satisfaction and organizational outcomes. Personnel Psychology, 58 (3): 613-640. doi: 10.1111/j.17446570.2005.00245.x

[15] Darling-Hammond, L. (2003). Keeping good teachers: Why it matters, what good leaders can do. Educational Leadership, 60 (8), 6-13.

[16] Dupriez, V., Delvaux, B., \& Lothaire, S. (2016). Teacher shortage and attrition: Why do they leave. British Education Research Journal, 42 (1), 21-39. doi: 10-1002/berj.3193

[17] Find Your Niche (2016). K-12. Retrieved from https://www.niche.com

[18] Flynt, S. W., \& Morton, R. C. (2009). The teacher shortage in America: Pressing concerns. National Forum of Teachers Education Journal, 19 (3), 1-5.

[19] Governing (2017). The states and localities: Education. Retrieved from http://www.governing.com.

[20] Gray, L., and Taie, S. (2015). Public school teacher attrition and mobility in the first five years: Results from the first through fifth waves of the 2007-08 beginning teacher longitudinal study (NCES 2015-337). U.S. Department of Education. Washington, DC: National Center for Education Statistics. Retrieved from http://nces.ed.gov/pubs2015/2015337.pdf.

[21] Hackett, G., Betz, N. E., \& Doty, M. S. (1985). The development of a taxonomy of career competencies for professional women. Sex Roles, 12 (3-4), 393-409.

[22] Ingersoll, R. (2001). Teacher turnover and teacher shortages: An organizational analysis. American Educational Research Journal, 38 (3), 499-534.

[23] Ingersoll, R. M. (2002). The teacher shortage: A case of wrong diagnosis and wrong prescription. NASSP Bulletin, 86 (631), 16-31.

[24] Ingersoll, R., Merrill, L. \& Stuckey, D. (2014). Seven trends: The transformation of the teaching force. Consortium for Policy Research in Education. CPRE Report (\#RR-80). Philadelphia: Consortium for Policy Research in Education, University of Pennsylvania. doi: 10-12698/cpre.2014.RR80.

[25] Ingersoll, R. M. \& Smith, T. M. (2003). The wrong solution to the teacher shortage. Educational Leadership, 60 (8), 30-33. Retrieved from http://www.gse.upenn.edu/pdf/rmi/EL_TheWrongSolution_to _theTeacherShortage.pdf.

[26] Johnson, D. (2010). Teachers' perceptions of factors that contribute to attrition. (Doctoral dissertation, Waldon University). Available from ProQuest Dissertations and Theses database. (UMI No. 3418949).

[27] Karabiyik, B. \& Korumaz, M. (2014). Relationship between teachers' self-efficacy perceptions and job satisfaction levels. Procedia - Social and Behavioral Sciences 116, 826-830. doi: 10.1016/j.sbspro.2014.01.305.

[28] Lee, V., Dedick, R., \& Smith, J. (1991). The effect of the social organization of schools on teachers' efficacy and satisfaction. Sociology of Education, 64 (3), 190-208. Retrieved from https://www.jstor.org/stable/2112851?seq=1\#page_scan_tab_c ontents.

[29] Lindqvist, P., Nordänger, U. K., \& Carlsson, R. (2014) Teacher attrition the first five years: A multifaceted image. Teaching and Teacher Education.40, 94-103. Retrieved from http://dx.doi.org/10.1016/j.tate.2014.02.005.

[30] Litwin, M. S. (1995). The survey kit: How to measure survey reliability and validity. Thousand Oaks, CA: SAGE Publications. Marinell, W. H. \& Johnson, S. M. (2014). Midcareer entrants to teaching: Who they are and how they may, or may not, change teaching. Educational Policy, 28 (6) 743-779. Retrieved from http://epx.sagepub.com.unr.idm.oclc.org/content/28/6/743.full. pdf + html.

[31] Mojavezia, A. \& Tamiz, M. P. (2012). The impact of teacher self-efficacy on the students' motivation and achievement. Theory and Practice in Language Studies, 2 (3), 483-491. Retrieved

from http://search.proquest.com.unr.idm.oclc.org/docview/1348130 503/fulltextPDF/781E6916 86A3432CPQ/8?accountid=452.

[32] Nieto, S. M. (2003). What keeps teachers going? Educational Leadership 60 (8), 14-18.

[33] Nunnally, J. C. (1967). Psychometric theory. New York, NY: McGraw-Hill.

[34] Pearson, A. \& Moomaw, R. (2005). The relationship between teacher autonomy and stress, job satisfaction, empowerment, and professionalism. Educational Research Quarterly, 29 (1), 37-53. doi: 10.1177/1362168810365236

[35] Perie, M., \& Baker, D. P. (1997). Job satisfaction among America's teachers: Effects of workplace conditions, background characteristics, and teacher compensation. Washington, DC: U. S. Department of Education. Retrieved from https://nces.ed.gov/pubs97/97471.pdf

[36] Perrachione, B. A., Rosser, V. J., \& Petersen, G. J. (2008). Why do they stay? Elementary teachers' perceptions of job satisfaction and retention. The Professional Educator, 32 (2), 1-17. Retrieved from http://files.eric.ed.gov/fulltext/EJ862759.pdf

[37] Public School Review (2017). Retrieved from http://www.publicschoolreview.com

[38] Raudenbush, S., Rowan, B., \& Cheong, Y. (1992). Contextual effects on the self-perceived efficacy of high school teachers. Sociology of Education, 65 (2), 150-167. Retrieved http://www.jstor.org.unr.idm.oclc.org/stable/2112680

[39] Reeves, D. (2004). Accountability at a crossroads. Leadership, 34 (2), 12-15, 36-37. 
[40] Robinson, J. S., Garton, B. L., \& Vaughn, P. R. (2007). Becoming employable: A look at graduates' and supervisors' perceptions of the skills needed for employment. NACTA Journal $51 \quad$ (2), 19-26. Retrieved from http://search.proquest.com.unr.idm.oclc.org/docview/2143804 08/fulltextPDF/FC8AFC4 C6CB144FFPQ/7?accountid=452.

[41] Ross, J. A., Hogaboam-Gray, A., \& Hannay, L. (2001). Effects of teacher efficacy on computer skills and computer cognitions of K-3 students. Elementary School Journal, 102 (2), 141-156. Retrieved from http://www.jstor.org.unr.idm.oclc.org/stable/1002205.

[42] Schiller, L. \& Hinton, C. (2015). It's true: happier students get higher grades. The Conversation. Retrieved from http://theconversation.com/its-true-happier-students-get-highe r-grades- 41488

[43] Spector, P. E. (1985). Measurement of human service staff satisfaction: Development of the job satisfaction survey. American Journal of Community Psychology, 13 (6), 693-713. Retrieved from http://link.springer.com.unr.idm.oclc.org/article/10.1007/BF00 929796.

[44] Spector, P. E. (1997). Job satisfaction: Application, assessment, causes, and consequences. Thousand Oaks, CA: Sage.

[45] State Report Card. (2015) Per pupil expenditures. Retrieved from http://www.nevadareportcard.com.
[46] Tschannen-Moran, M. \& Woolfolk-Hoy, A. (2007). The differential antecedents of self-efficacy beliefs of novice and experienced teachers. Teaching and Teacher Education 23 (6), 944- 956.9 Retrieved from http://www.sciencedirect.com/science/article/pii/S0742051X0 6000953.

[47] Walker, T. (2014). NEA survey: Nearly half of teachers consider leaving profession due to standardized testing. Retrieved

from http://neatoday.org/2014/11/02/nea-survey-nearly-

half-of-teachers-consider-leaving-profession-due-to-standardiz ed-testing-2/.

[48] Weinstein, C. S. (1988). Preservice teachers' expectations about the first year of teaching. Teaching and Teacher Education, 4 (1), 31-40. doi: 10.1016/0742-051X (88)90022-4

[49] Westervelt, E. (Education Correspondent), Block, M (Host), \& Evstatieva, M. (Director). (2015). Where have all the teachers gone? [Radio Broadcast]. In Carline Watson (Executive Producer), All Things Considered. Washington, D. C., National Public Radio. Retrieved from http://www.npr.org/sections/ed/2015/03/03/389282733/wherehave-all-the- teachers-gone.

[50] Wheatley, K. F. (2002). The potential benefits of teacher efficacy doubts for educational reform. Teaching and Teacher Education, 18 (1), 5-22. doi: 10.1016/S0742-051X (01) 00047-6. 